\title{
ANALISIS LAJU KOROSI PADA METERIAL BAJA ASTM A36 AKIBAT PENGARUH SUDUT BENDING DAN ALIRAN MEDIA KOROSI $\mathrm{H}_{2} \mathrm{SO}_{4} 10 \%$
}

\author{
M.F. Farkhani*, H. Purwanto,dan M. Dzulfikar \\ Jurusan Teknik Mesin, Fakultas Teknik, Universitas Wahid Hasyim \\ Jl. Menoreh Tengah X/22, Sampangan, Semarang 50236. \\ "Email: mmspaik73@gmail.com
}

\begin{abstract}
Abstrak
Penelitian ini bertujuan untuk mengetahui pengaruh asam sulfat $\left(\mathrm{H}_{2} \mathrm{SO}_{4}\right) 10 \%$ terhadap laju korosi pada plat baja karbon rendah mild steel ASTM A36 yang banyak digunakan salah satunya untuk konstruksi pintu air. Dalam penelitian ini plat akan mendapat perlakuan bending dan dicelup menggunakan metode celup diam dan celup putar dengan variasi bending yang digunakan adalah $60^{\circ}, 90^{\circ}, 120^{\circ}$, dan $180^{\circ}$ dengan lama waktu pencelupan 30 , 60, dan 90 menit. Ukuran spesimen yang akan diuji dengan panjang $100 \mathrm{~mm}$, lebar $50 \mathrm{~mm}$, dan tebal $3 \mathrm{~mm}$ sebanyak 8 spesimen. Hasil dari pengujian menunjukan bahwa laju korosi pada baja ASTM A36 menggunakan metode celup diam laju korosi terbesarnya pada sudut $180^{\circ}$ dengan waktu pencelupan 30 menit yaitu sebesar156,46 mm/tahun. Sedangkan untuk metode celup putar laju korosi terbesarnya terdapat pada sudut $90^{\circ}$ dengan waktu 30 menit nilainya sebesar 40,56 mm/tahun. Laju korosi terbesar terhadap ke 2 metode tersebut terdapat pada pencelupan menit 30 ini dikarenakan pada menit 30 kadar keasaman pada larutan $\mathrm{H}_{2} \mathrm{SO}_{4}$ masih tinggi dan belum terkontaminasi oleh lingkungan. Aliran media pengkorosi larutan $\mathrm{H}_{2} \mathrm{SO}_{4} 10 \%$ dengan menggunakan metode celup putar pengaruhnya kecil terhadap laju korosi dan pada penelitian ini sudut bending pada plat baja ASTM A36 tidak terlalu berpengaruh besar terhadap laju korosi ini dikarenakan gaya tekan yang diterima spesimen kecil.
\end{abstract}

Kata kunci: Baja karbon rendah ASTM A36, korosi, bending, asam sulfat $\mathrm{H}_{2} \mathrm{SO}_{4}$, variasi metode celup

\section{PENDAHULUAN}

Korosi merupakan fenomena alamiah yang terjadi pada material logam, dimana korosi merupakan proses kerusakan material karena reaksi kimia atau elektrokimia dengan lingkungannya. Korosi banyak dijumpai dalam kehidupan sehari-hari, contohnya keroposnya besi penyangga jembatan, kebocoran pipa gas, kebocoran kapal laut, dan konstruksi mesin lainnya. Korosi tidak dapat dihentikan akan tetapi bisa dicegah yaitu dengan melapisi dengan oli, cat, dan logam lain yang tahan korosi. Threthewey, (1991) menyatakan bahwa korosi merupakan kerusakan material yang disebabkan oleh pengaruh lingkungan sekelilingnya. Proses korosi terjadi oleh reaksi kimia dan elektrokimia yang melibatkan perpindahan panas elektron dari reduksi ion logam maupun pengendapan logam dari lingkungan sekeliling seperti lingkungan asam, udara, embun, air sungai. Elektrolit sangat berpengaruh terhadap korosi dalam lingkungan air.

Baja kerbon rendah (low carbon steel/mild steel) merupakan baja yang mempunyai kandungan karbon maksimal 0,3\% C. baja ini terdiri dari ferrite dan sedikit perlite sehingga baja ini mempunyai sifat kekerasan yang relativ rendah, lunak dan keuletannya tinggi serta mudah di bending dan machining serta mudah untuk dilakukan pengelasan. Baja karbon rendah banyak dipakai sebagai konstruksi jembatan, rangka bangunan, plat kapal laut, konstruksi pintu air irigasi dan lainnya. Oleh sebab itu baja ini mudah terserang oleh korosi .

Pada penelitian ini menggunakan baja karbon rendah jenis mild steel ASTM A36 yang biasa digunakan sebagai structural steel plates atau sebagai lembaran plat. Pada pengaplikasiannya baja ini sering mendapat perlakuan tekuk (bending) seperti pada bodi kapal laut, pagar rumah dan lainnya. Dari proses bending tersebut menyebabkan perubahan struktur tegangan mikro dan tegangan sisa, ini akan berpengaruh pada sifat mekanis dan laju korosi. Putri, dkk.,(2012) menyatakan laju korosi pada pipa yang diberi perlakuan bending akan menghasilkan tensile dan compress maka akan mengakibatkan stress, dari gaya ini timbul retakan-retkan yang mengakibatkan terjadinya korosi.

Sudut bending sangat berpengaruh terhadap laju korosi, semakin kecil sudut bending maka semakin besar tingkat laju 
korosinya (Permadi \& Palupi, 2014). Lamanya pencelupan juga sangat berpengaruh terhadap korosi, semakin meningkatnya waktu pencelupan, semakin besar pula laju krosi pada baja karbon dan paduan tembaga (Pattireuw, dkk., 2013). Tujuan dari penelitian ini adalah untuk mengetahui dan menganalisa media pengkorosi $\left(\mathrm{H}_{2} \mathrm{SO}_{4}\right)$ terhadap laju korosi pada baja mild steel ASTM A36 yang diberi perlakuan bending serta mengetahui aliran media pengkorosi $\left(\mathrm{H}_{2} \mathrm{SO}_{4}\right)$ terhadap laju korosi pada baja mild steel ASTM A36 yang diberi perlakuan bending

\section{METODOLOGI}

Penelitian laju korosi pada material baja ASTM A36 akibat pengaruh sudut bending dan aliran media korosi ini dilakukan di laboratorium material fakultas teknik UNWAHAS. Penelitian menggunakan bahan material baja karbon rendah dalam bentuk plat mild steel jenis ASTM A36 dengan komposisi seperti pada tabel 1 dengan ukuran panjang 100 $\mathrm{mm}$, lebar $50 \mathrm{~mm}$, tebal $3 \mathrm{~mm}$ dan larutan $\mathrm{H}_{2} \mathrm{SO}_{4}$ serta aquades.

Tabel 1 hasil uji komposisi kimi baja ASTM

\begin{tabular}{|c|c|c|c|c|c|}
\hline $\begin{array}{c}\text { Simbol } \\
\text { unsur }\end{array}$ & $\begin{array}{c}\text { Persentase } \\
(\%)\end{array}$ & $\begin{array}{c}\text { Simbol } \\
\text { unsur }\end{array}$ & $\begin{array}{c}\text { Persentase } \\
(\%)\end{array}$ & $\begin{array}{c}\text { Simbol } \\
\text { unsur }\end{array}$ & $\begin{array}{c}\text { Persentase } \\
(\%)\end{array}$ \\
\hline $\mathrm{Fe}$ & 99,6139 & V & 0,000 & B & 0,0002 \\
\hline$S$ & 0,0127 & Mn & 0,2214 & $\mathrm{~Pb}$ & 0,000 \\
\hline Al & 0,0382 & $\mathrm{M}_{0}$ & $-0,0019$ & $\mathrm{Sb}$ & 0,0041 \\
\hline C & 0,0324 & W & $-0,0014$ & $\mathrm{Ca}$ & 0,0000 \\
\hline $\mathrm{Ni}$ & 0,0031 & $P$ & 0,0135 & Mg & $-0,0003$ \\
\hline $\mathrm{Nb}$ & 0,0003 & $\mathrm{Cu}$ & 0,0108 & Sn & 0,0011 \\
\hline $\mathrm{Si}$ & 0,0074 & $\mathrm{Ti}$ & 0,0008 & $\mathrm{C}_{0}$ & 0,0016 \\
\hline $\mathrm{Cr}$ & 0,0161 & $\mathrm{~N}$ & 0,0168 & & \\
\hline
\end{tabular}

Peralatan yang digunakan pada penelitian ini adalah mesin pemutar media korosi, neraca digital, foto makro, kamera digital, gelas ukur, beaker glass, ragum/tanggem, gerinda potong, mesin bor, tang kombinasi, jangka sorong, busur derajat, pistol pemanas (hot gun), Stopwatch, 1 ember plastik, amplas, tisu, benang, dan sarung tangan karet.

\section{Prosedur Penelitian}

\section{Pembuatan spesimen}

Material dipotong menjadi 8 spesimen dengan ukuran per spesimennya panjang $100 \mathrm{~mm}$, lebar $50 \mathrm{~mm}$. Material uji akan di tekuk (bending) dengan variasi bending $60^{\circ}, 90^{\circ}, 120^{\circ}$, dan $180^{\circ}$. Sebelum pencelupan spesimen akan dibersihkan menggunakan gerinda amplas sampai permukaannya halus ini sesuai dengan standar ASTM G-90 (Standart Practice for Preparing, Cleaning, and Evaluating Corrosion test spesimens).

2. Analisis pengujian korosi

Untuk mengetahui tingkat korosifitas pada plat baja ASTM A36 maka pada penelitian ini menggunakan larutan $\mathrm{H}_{2} \mathrm{SO}_{4}$ sebesar $10 \%$, dengan variasi waktu pencelupan 30, 60, dan 90 menit. Adapun tahapan dari penelitian ini adalah:

a. Penimbangan berat awal spesimen

b. Mempersiapkan larutan pengkorosi $\mathrm{H}_{2} \mathrm{SO}_{4}$ sebanyak $10 \%$ dan aquades.

c. Perendaman spesimen pada larutan $\mathrm{H}_{2} \mathrm{SO}_{4}$ selama 30, 60, dan 90 menit.

d. Penimbangan berat akhir spesimen.

e. Pengamatan spesimen menggunakan foto makro.

\section{Teknik Analisis Data}

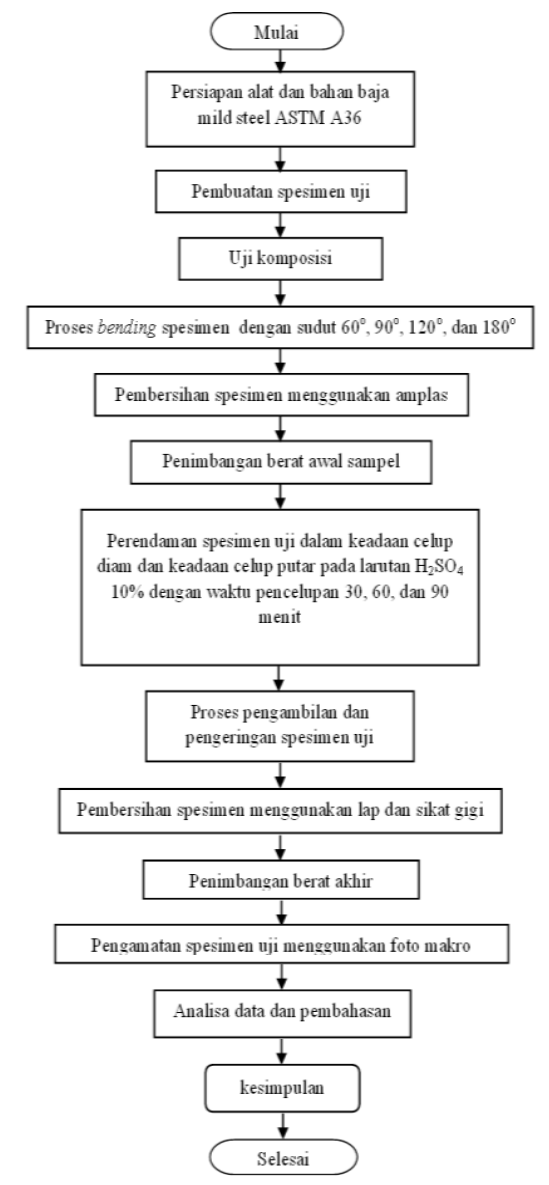

Gambar 1. Diagram alir penelitian 
Teknik analisis data menggunakan metode gravimetric. Teknik ini merupakan suatu analisis kuantitatif yang bergantung pada proses penimbangan. Tujuannya adalah menghitung laju korosi berdasarkan berat yang hilang terhadap waktu perendaman. Cara menghitungnya yaitu dengan rumus:

$$
C R=\frac{K \times W}{A \times T \times D}
$$

Dimana laju korosi $C R$ (mm/ tahun), Berat yang hilang $\mathrm{W}(\mathrm{g})$, Konstanta faktor $\mathrm{mm} / \mathrm{tahun}$ K $8,76 \times 10^{4}$, Luas A $\left(\mathrm{cm}^{2}\right)$, Waktu T (jam), Density D untuk baja $7,86\left(\mathrm{~g} / \mathrm{cm}^{3}\right) \quad$ (Standart ASTM G1-90).

\section{HASIL DAN PEMBAHASAN \\ Hasil Pengujian Laju Korosi \\ Laju korosi pada larutan $\mathrm{H}_{2} \mathrm{SO}_{4} 10 \%$ dalam keadaan diam. \\ Gambar 2 grafik hasil pengujian laju} korosi baja ASTM A36 menggunakan metode celup dengan larutan pengkorosi asam sulfat $\mathrm{H}_{2} \mathrm{SO}_{4} \quad 10 \%$ dalam keadaan diam. Setelah dilakukan pengujian laju korosi pada baja ASTM A36, terdapat perubahan berat pada spesimen antara sebelum pencelupan dan sesudah pencelupan. Berdasarkan perhitungan laju korosi secara manual diperoleh data seperti diperlihatkan pada Gambar grafik 2.

Berdasarkan dari data grafik gambar 2 menunjukan bahwa laju korosi pada semua variasi sudut bending mengalami penurunan seiring dengan naiknya waktu pencelupan. Laju korosi terbesar pada waktu penceluan 30 menit terdapat pada sudut $180^{\circ}$ dengan nilai laju korosi sebesar 156,46 mm/tahun. Pada pencelupan dengan waktu 60 menit laju korosi terbesarnya yaitu pada sudut $120^{\circ}$ dengan nilai $108,17 \mathrm{~mm} /$ tahun. Sedangkan pada waktu pencelupan 90 menit laju korosi terbesarnya pada sudut $120^{\circ}$ nilainya yaitu $82,42 \mathrm{~mm} /$ tahun.

Dari percobaan pengujian korosi dengan metode celup diam dapat diketahui bahwa semakin lama waktu pencelupan menyebabkan proses laju korosi pada baja ASTM A36 semakin kecil. Ini berarti bahwa pada pengujian menit 60 dan 90 menit berat yang hilang (weight loss) mengalami kenaikan akan tetapi nilai kenaikannya tidak terlalu besar jika dibandingkan dengan menit ke 30 menit. Jadi jarak nilai kehilangan berat pencelupan menit pertama 30 dengan pencelupan menit 60 dan 90 nilainya terpaut jauh dengan kata lain pada metode celup diam nilai laju korosi terbesarnya pada menit ke 30 .

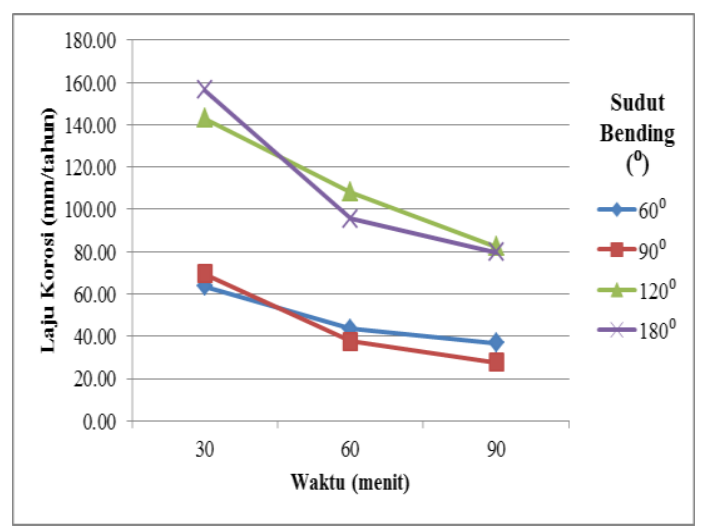

Gambar 2. Grafik laju korosi pada baja ASTM A36 dengan media pengkorosi $\mathrm{H}_{2} \mathrm{SO}_{4}$ dalam keadaan diam.

Naiknya laju korosi pada percobaan pertama karena permukaan logam awalnya masih bersih belum terbentuk korosi yang menempel pada baja. Sehingga pada pencelupan pertama kali masih efektif mengadakan kontak dan bereaksi secara langsung dengan lingkungan. Sedangkan penurunan laju korosi pada menit berikutnya disebabkan karena sudah terbentuknya korosi sejak awal pada permukaan logam (Tjitro, dkk., 2000).

Kurangnya faktor pengaruh sudut bending pada penelitian ini disebabkan oleh faktor ketika proses penekukan platnya, kurangnya penekanan pada logam yang akan ditekuk sehingga menyebabkan berkurangnya tarikan pada sisi luar sumbu netral. Mengapa pada metode celup diam laju korosi terbesarnya pada sudut $180^{\circ}$, ini dikarenakan luas permukaan mempengarui besarnya laju korosi (Ridluwan, 2007).

Pada penelitian menggunakan metode celup diam ini korosi yang terjadi adalah jenis korosi merata (uniform corrosion) yaitu korosi yang terjadi pada seluruh permukaan spesimen, logam yang terbuka atau kontek langsung dengan larutan yang bersifat asam. Korosi ini terjadi pada permukaan logam yang berbentuk pengikisan logam secara merata.

Laju korosi pada larutan $\mathrm{H}_{2} \mathrm{SO}_{4} 10 \%$ dalam keadaan berputar

Gambar 3 garfik hasil pengujian laju korosi baja ASTM A36 menggunakan metode 
celup dengan larutan pengkorosi asam sulfat $\mathrm{H}_{2} \mathrm{SO}_{4} 10 \%$ dalam keadaan berputar.

Gamar 3 merupakan hasil pengujian laju korosi pada baja ASTM A36 dengan metode putar selama 30, 60, dan 90 menit, dengan menghitung mengunakan perhitungan secara manual. Maka diperoleh data laju korosi seperti diperlihatkan pada Gambar 3.

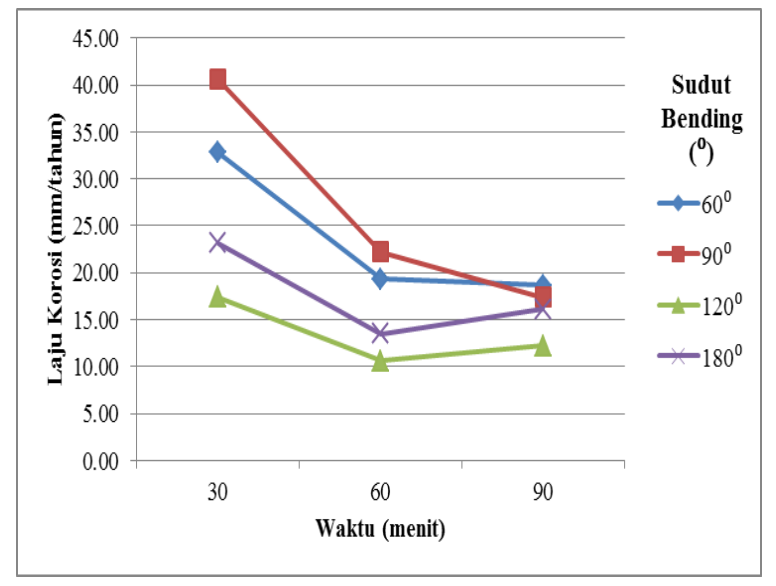

\section{Gambar 3. Grafik laju korosi pada baja ASTM A36 dengan media pengkorosi $\mathrm{H}_{2} \mathrm{SO}_{4}$ $10 \%$ dalam keadaan berputar.}

Dari gambar grafik 3 dapat diamati bahwa semakin lama pencelupan maka terdapat perbedaan penurunan berat yang hilang (weight loss). Pada pencelupan pertama 30 menit mengalami pengikisan spesimen dengan nilai yang cukup besar, sedangkan pada waktu pencelupan 60 dan 90 menit juga mengalami kenaikan akan tetapi nilai kenaikannya laju korosinya tidak terlalu besar jika dibandingkan dengan pencelupan 30 menit. Meningkatnya nilai laju korosi ini diakibatkan karena material berinteraksi langsung dengan zat-zat korosif sepert asam sulat $\mathrm{H}_{2} \mathrm{SO}_{4}$.

Nilai laju korosi terbesar pada waktu pengujian 30 menit adalah sebesar 40,56 $\mathrm{mm} / \mathrm{tahun}$ yaitu pada sudut $90^{\circ}$. Pengujian korosi pada waktu pencelupan 60 dan 90 menit mengalami penurunan nilai laju korosinya seperti pada perendaman dengan waktu 60 menit laju korosi paling besarnya dengan nilai $22,21 \mathrm{~mm} /$ tahun yaitu pada sudut bending $90^{\circ}$. Sedangkan pada waktu pencelupan 90 menit laju korosi terbesarnya pada sudut $60^{\circ}$ dengan nilai sebesar 18,67 mm/tahun.

Penelitian tentang laju krosi pada baja ASTM A36 dengan larutan pengkorosi $\mathrm{H}_{2} \mathrm{SO}_{4}$ $10 \%$ dengan metode celup putar ini mengalami penurunan laju korosi seiring dengan bertambahnya waktu pencelupan. Ini disebabkan karena faktor keasaman $(\mathrm{pH})$ pada larutan $\mathrm{H}_{2} \mathrm{SO}_{4}$ mengalami penurunan setelah pengujian pertama dan pada saat pengujian menit pertama logam masih dalam keadaan bersih belum terkontaminasi oleh zat-zat korosif. Tjitro, dkk., (2000) menyatakan pada penelitiannya bahwa penurunan keasaman secara drastis terjadi setelah pengujian pertama,kemudian cenderung konstan pada pengujian ke dua dan seterusnya, penurunan asam ini penyebabnya adalah karena terjadi hidrolisis antara ion-ion logam dengan molekulmolekul air yang menghasilkan ion-ion hydrogen yang mengurangi tingkat keasaman $(\mathrm{pH})$. Faktor penyebab tidak stabilnya kehilangan berat (weight loss) dan nilai laju korosi adalah ukuran spesimen yang tidak seragam, permukaan spesimen yang tidak rata, dan proses pembersihan spesimen yang tidak optimal atau kurang bersih (Ojehan R \& Winata S, 2013).

Kurangnya pengaruh sudut bending terhadap laju korosi pada metode putar ini dikarenkan faktor gaya tekan (compress) yang diterima sudut $60^{\circ}, 90^{\circ}$, dan $120^{\circ}$ tidak terlalu besar sehingga tidak mengakibaatkan stress yang berlebih dan laju korosinya juga tidak berpengaruh besar terhadap sudut-sudut tersebut. Metode pencelupan yaitu dengan larutan $\mathrm{H}_{2} \mathrm{SO}_{4}$ dalam keadaan diputar juga berpengaruh terhadap korosi meskipun kecil ini disebabkan karena putaran pada mesin penguji korosi tersebut berputar hanya dengan kecepatan 14 rpm saja, hal ini juga dijelaskan pada penelitian Asmara, (2008) tentang kecepatan aliran minyak terhadap kecepatan korosi dalam pipa yang menyatakan pengaruh aliran minyak terhadap korosi dipengarui oleh besar kecepatannya, kecepatan korosi yang tinggi terjadi pada kecepatan aliran yang tinggi.

Faktor jarak waktu percobaan juga dapat mempengarui tingkat laju korosi antara metode pencelupan pertama (celup diam) dan kedua (celup putar) jeda waktunya terlalu lama ini juga dapat menyebabkan kandungan tingkat keasaman $(\mathrm{pH})$ pada $\mathrm{H}_{2} \mathrm{SO}_{4}$ berkurang karena sudah terkntaminasi dengan larutan sekitar ini mengakibatkan berat yang hilang (weight loss) semakin kecil dan nilai laju korosinya juga rendah. 
Perbandingan laju korosi metode celup diam dengan metode celup putar

Data grafik hasil perbandingan laju korosi pada baja karbon rendah ASTM A36 dengan media pengkorosi $\mathrm{H}_{2} \mathrm{SO}_{4} 10 \%$ menggunakan metode celup diam dan metode celup putar dapat dilihat pada Gambar 4.

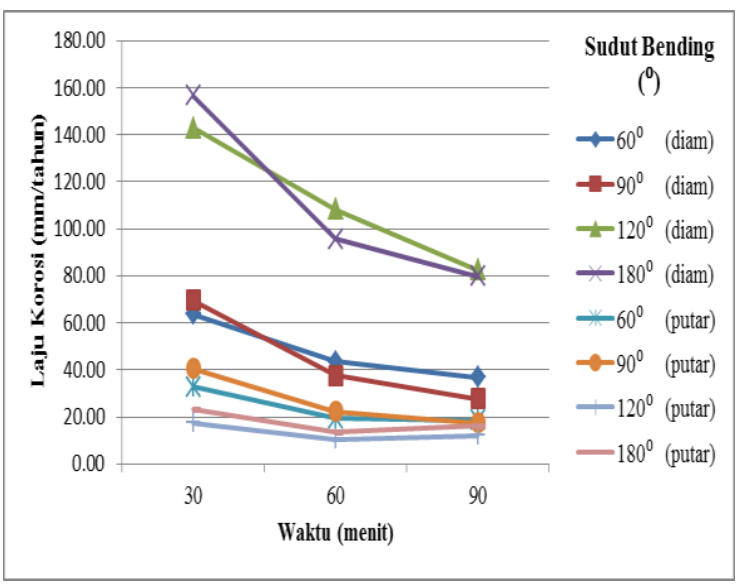

Gambar 4 Grafik perbandingan laju korosi metode celup diam dan metode celup putar dengan media pengkorosi $\mathrm{H}_{2} \mathrm{SO}_{4} 10 \%$.

Perbandingan laju korosi karbon rendah ASTM A36 dengan menggunakan metode celup diam dan celup putar berdasarkan dari hasil data pengujian menunjukan bahwa terdapat perbedaan rata-rata laju korosi pada media tersebut. Peercobaan metode celup diam laju korosinya sangat meningkat sedangkan pada metode celup putar laju korosinya menurun atau lebih kecil jika dibandingkan dengan metode celup diam.

Pada metode celup diam laju korosinya meningkat pada percobaan perendaman pertama 30 menit, sedangkan pada perendaman menit ke 60 dan 90 laju korosinya mengalami penurunan. Laju korosi terbesar pada metode celup diam terdapat pada sudut $180^{\circ}$ dengan waktu pencelupan 30 menit, ini dikarenakan semakin luas penampang plat maka reaksi larutan kimia akan semakin cepat pula daya korosinya (Rahman, dkk., 2016). Sedangkan pada metode celup putar hasilnya hampir sama dengan metode celup diam tetapi berbeda nilai laju korosinya atau nilai kehilangan beratnya pada metode celup putar laju korosi terbesarnya juga pada pencelupan yang pertama yaitu 30 menit.

Pengaruh kecilnya laju korosi pada metode putar juga disebabkan karena tingkat keasaman $\mathrm{pH}$ larutan asam sulfat $\mathrm{H}_{2} \mathrm{SO}_{4}$ mengalami penurunan setelah pengujian pertama (celup diam) dan larutan asam sulfat sudah terkontaminasi dengan zat-zat di lingkungan sekitar dan akibatnya daya korosinya juga menurun.

Waktu juga sangat berpengaruh, dengan bertambahnya waktu pencelupan maka beban yang hilang (weight loss) semakin bertambah akan tetapi pada penelitian ini beban yang hilang pada menit 60 dan 90 tidak lebih besar jika dibandingkan pada pencelupan menit pertama yaitu 30 menit. Hal ini dikarenakan pada waktu pencelupan pertama sudah molai ada produk korosi yang terbentuk pada permukaan spesimen uji dan ini akan menghambat kontak antara logam dengan elektrolit sehingga laju korosi untuk percobaan seterusnya akan terhambat dan nilai laju korosinya juga kecil (Sumarji, 2012). Percobaan laju korosi dengan metode celup putar hasilnya lebih kecil jika dibandingkan metode celup diam penyebabnya yaitu faktor keasaman $(\mathrm{pH})$ pada larutan asam sulfat yang berkurang karena pengaruh lingkumgan sekitar.

\section{Foto Makro Korosi pada permukaan plat}

Korosi yang dicelup pada media asam sulfat $\mathrm{H}_{2} \mathrm{SO}_{4} 10 \%$ dalam keadaan celup diam dengan variasi sudut bending $60^{\circ}, 90^{\circ}, 120^{\circ}$, dan $180^{\circ}$ dengan waktu perendaman 30 menit seperti pada Gambar 5.
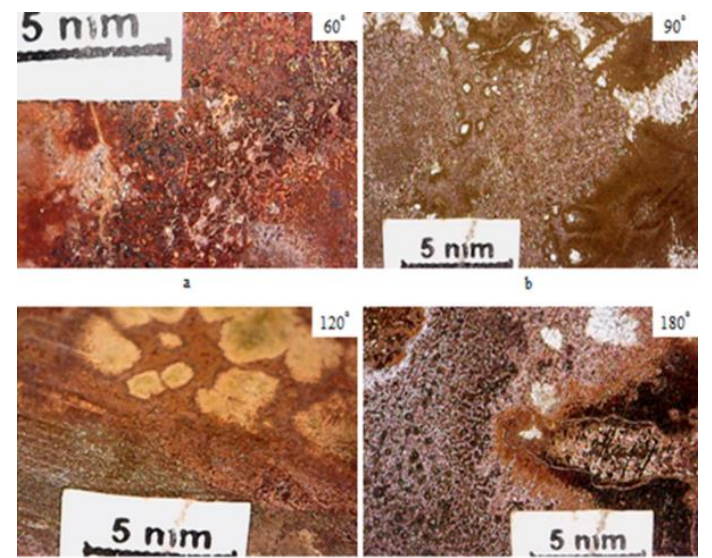

Gambar 5. Korosi permukaan (a) sudut bending $60^{\circ}$, (b) sudut bending $90^{\circ}$, (c) sudut bending $120^{\circ}$, dan (d) sudut bending $\mathbf{1 8 0}^{\circ}$ dengan waktu pencelupan 30 menit menggunakan media celup diam.

Gambar 5 menunjukan bahwa dari hasil pengamatan foto makro pada spesimen (a) sudut bending $60^{\circ}$ laju korosinya sangat 
meningkat dan kerusakan akibat korosi sangat jelas terlihat, pada spesimen yaitu ditandai dengan permukaan yang kasar dan tidak halus lagi seperti sebelum dilakukan penelupan, ini disebabkan karena molekul-molekul pada plat baja tersebut sudah berubah ikatannya. Korosi ini juga mengakibatkan permukaan logam menjadi tidak rata karena lapisan film pelindung pada permukaan logam terkelupas. Produk korosi dapat berakibat permukaan logam menjadi tidak rata, hal ini menimbulkan terlepasnya lapisan film pada permukaan logam sehingga akan terjadi korosi pada anoda yang menjadikan logam logam higroskopik (Sumarji, 2012). Warna plat juga sudah berubah menjadi coklat kemerah-merahan dan timbul bintikbintik hitam, dimana plat ini sudah molai terkena korosi dan ini merupakan korosi jenis korosi merata.

Pada spesimen (b) yaitu sudut $90^{\circ}$ nampak warnanya juga berubah menjadi coklat dan sedikit ada bercak-bercak putih yaitu scale (kerak) yang menempel pada permukaan logam, hal ini dapat menimbulkan korosi. Bercakbercak putih ini disebabkan karena lapisan permukaan logam tersebut telah teroksidasi dengan adanya larutan asam sulfat $\mathrm{H}_{2} \mathrm{SO}_{4}$ yang bersifat asam. Spesimen (c) sudut $120^{\circ}$ juga menggalami perubahan warna yang tadinya spesimen dalam keadaan bersih dan warnanya abu-abu karena telah dicelup pada larutan $\mathrm{H}_{2} \mathrm{SO}_{4}$ berubah warnanya menjadi coklat setelah spesimen melalui proses pengeringanyaitu dengan cara dijemur.

Sedangka pada spesimen (d) sudut $180^{\circ}$ perubannya hampir sama dengan spesimen (c) sudut $90^{\circ}$ akan tetapi pada spesimen Dtrdapat bercak hitam yang mana ini dapat menimbulkan. Korosi yang terjadi pada saat metode celup diam adalah jenis korosi merata (uniform corrosion). Korosi ini terjadi pada permukaan logam yang berbentuk pengikisan logam secara menyeluruh atau merata sehingga ketebalan logam berkurang. Korosi pada permukaan plat yang dicelup pada media asam sulfat $\mathrm{H}_{2} \mathrm{SO}_{4} 10 \%$ dalam keadaan diputar (celup putar) dengan variasi sudut bending $60^{\circ}, 90^{\circ}$, $120^{\circ}$, dan $180^{\circ}$ dengan waktu perendaman 30 menit seperti terlihat pada Gambar 6.

Pada saat proses logam dicelupkan kedalam aquades dan asam sulfat $10 \%$ terdapat gelembung-gelembung pada permukaan logam tersebut. Hal ini menunjukan bahwa logam tersebut telah teroksidasi dengan adanya larutan asam sulfat $\mathrm{H}_{2} \mathrm{SO}_{4}$. Proses ini terjadi pada semua metode baik itu metode celup diam maupun metode celup putar serta pada semua variasi sudut bending. Oleh sebab itu semakin lama spesimen dicelupkan kedalam larutan $\mathrm{H}_{2} \mathrm{SO}_{4}$ maka akan semakin banyak pula pengikisan pada baja tersebut. Terlihat pada Gambar 6 spesimen (a) sudut $60^{\circ}$ warnanya berubah menjadi coklat dan sedikit bercakbercak putih, ini terjadi pada bagian sudut bending dan permukaan-permukaan lainnya yang dicelup.
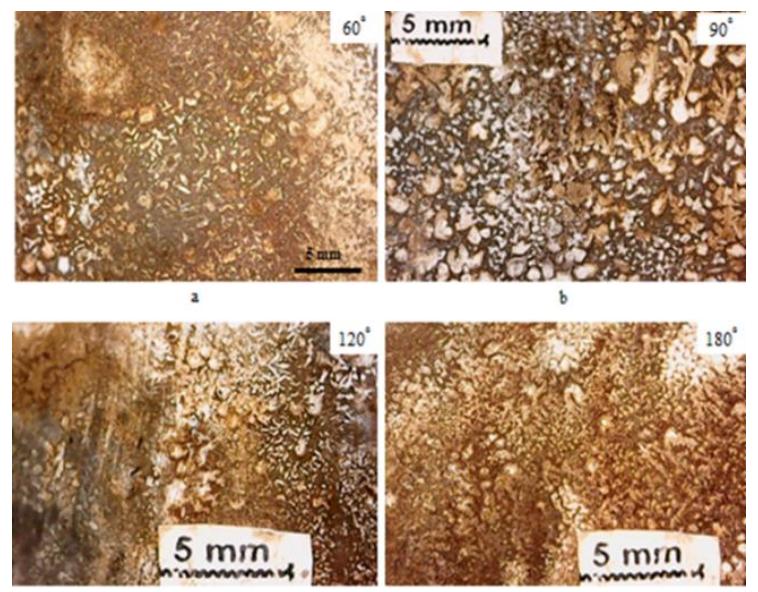

Gambar 6 Korosi permukaan (a) sudut bending $60^{\circ}$, (b) sudut bending $90^{\circ}$, (c) sudut bending $120^{\circ}$, dan (d) sudut bending $\mathbf{1 8 0}^{\circ}$ dengan waktu pencelupan 30 menit menggunakan metode celup putar.

Pada spesimen (b) sudut $90^{\circ}$ warnanya coklat kehitaman dan lebih banyak terdapat bercak-bercak putih yang menempel pada permukaan baja tersebut jika dibandingkan pada spesimen (a) yang hanya terdapat sedikit bercak putihnya. Ini akan berakibat pada rusaknya lapisan pelindung baja tersebut atau lapisan film pelindung baja tersebut terkelupas serta akan mengakibatkan korosi.

Korosi juga nampak seperti pada Gambar (c) dengan sudut bending $120^{\circ}$ perubahan warnanya dari sebelum dicelup hingga sesudah dicelup nampak jauh berbeda, sebelum dicelup baja terlihat mengkilap dan halus dan sesudah dilakukan pencelupan baja berubah warna menjadi abu-abu dan halus akan tetapi warna baja akan berubah lagi ketika baja sudah molai tahap pengeringan, baja akan tampak coklat kehitaman dan disertai pula dengan bercakbercak putih serta permukaannya kasar seperti terlihat pada Gambar 6. Sedangkan pada gambar (d) yaitu sudut bending $180^{\circ}$ kerusakan akibat korosi pada baja mild steel ASTM A36 
sangat jelas terlihat, spesimen yang mengalami korosi ditandai oleh berubahnya warna logam menjadi coklat dan permukaannya kasar.

\section{KESIMPULAN}

Dari data hasil penelitian tentang analisis laju korosi pada meterial baja ASTM A36 akibat pengaruh sudut bending dan aliran media korosi $\mathrm{H}_{2} \mathrm{SO}_{4} \quad 10 \%$ maka dapat disimpulkan bahwa:

1. Sudut bending pada plat baja mild steel ASTM A36 tidak terlalu berpengaruh besar terhadap laju korosinya. Korosi yang terjadi pada plat baja ini adalah jenis korosi merata (uniform corrosion), korosi ini terjadi pada permukaan yang berbentuk pengikisan logam secara merata.

2. Nilai laju korosi menggunakan metode celup diam dan celup putar pada baja mild steel ASTM A36 dengan media $\mathrm{H}_{2} \mathrm{SO}_{4} \quad 10 \%$ mengalami penurunan seiring dengan bertambahnya waktu pencelupan. Nilai laju korosi terbesar pada metode celup diam adalah $156,46 \mathrm{~mm} /$ tahun pada sudut $180^{\circ}$ dengan waktu pencelupan 30 menit sedangkan laju korosi terbesar pada metode celup putar yaitu pada sudut $90^{\circ}$ dengan waktu pencelupan 30 menit nilainya sebesar 40,56 $\mathrm{mm} /$ tahun lebih kecil jika dibandingkan dengan metode celup diam.

3. Perbandingan laju korosi pada plat baja mild steel ASTM A36 antara metode celup diam dengan metode celup putar hasilnya sangat meningkat ketika menggunakan media celup diam, sedangkan pada metode celup putar nilai laju korosinya menurun. Pada ke dua metode tersebut nilai laju korosinya samasama meningkat pada saat pencelupan pertama yaitu 30 menit.

4. Aliran media pengkorosi larutan asam sulfat $\mathrm{H}_{2} \mathrm{SO}_{4} \quad 10 \%$ yaitu dengan menggunakan metode putar pengaruhnya kecil terhadap laju korosi, sehingga nilai laju korosi yang dihasilkanya pun kecil tidak sebanding dengan menggunakan metode celup diam.

\section{SARAN}

Dalam penelitian selanjutnya supaya memisahkan larutan pengkorosi asam sulfat $\mathrm{H}_{2} \mathrm{SO}_{4}$ dibagi menjadi dua dalam wadah yang berbeda akan tetapi konsentrasi tetap sama, ini bertujuan untuk dapat membedakan hasil antara metode celup diam dengan metode celup putar, sehingga pengujiannya bisa beriringan.
Menambah variasi kecepatan pada mesin penguji laju korosi metode putar supaya dapat membandingkan antara kecepetan satu dengan yang lainnya.

\section{DAFTAR PUSTAKA}

Asmara, Y. P. (2008). Efek Kecepatan Aliran Minyak Terhadap Kecepatan Korosi Dalam Pipa di Lingkungan Minyak dan Gas Bumi. Media Teknika Fakultas Teknik Universitas Mataram, 61-68, Vol 8, No 1.

Ojehan R, T., \& Winata S, J. (2013). Perhitungan laju korosi pada material baja A36 akibat proses pengelasan SMAW (Shielded Metal Arc Welding). Jurnal mechanical, Fakultas Teknik Mesin Universitas Malahayati, vol,4 no, 1 .

Pattieuw, K., Rauf, F., \& Lumintang, R. (2013). Analisa Laju Korosi Pada Baja Karbon Dengan Menggunakan Air Laut Dan $\mathrm{H}_{2} \mathrm{SO}_{4}$. Teknik Mesin, Universitas Sam Ratulangi Manado.

Permadi, L. B., \& Palupi, A. E. (2014). Analisa Laju Korosi Pada Baja Karbon Rendah (Mild Steel) Dengan Perlakuan Bending Pada Media Pengkorosi Larutan Asam. JTM Universitas Negeri Surabaya, 49-54, Vol 3, No 1.

Putri, A. M., Rochani, I., \& Supomo, H. (2012). Studi Laju Korosi dan Surface Morfologi Pipa Bawah Laut API 5L Grade X65 dengan Variasi Sudut Bending. Jurnal Teknik ITS, 198-202, Vol 1, ISSN: 2301 9271.

Rahman, L. A., Hasbi, M., \& Aminur. (2016). Analisa Laju Korosi Pada Baja Karbon Rendah Yang Dilapisi Seng Dengan Metode Hot Dip Galvanizing. ENTALPHY- Jurnal Ilmiah Mahasiswa Teknik Mesin e-ISSN:2502-8944 Universitas Halu Oleo, Vol.1 No.2.

Ridluwan, M. (2007). Pengaruh Temperatur Pencelupan Terhadap Kekerasan, Laju Korosi dan Stuktur Mikro Pada Baja Karbon Rendah Dengan Pelapisan Metode Hot Dip Galvanizing. Fakultas Teknik Universitas Negeri Semarang.

Sumarji. (2012). Evaluasi Korosi Baja Karbon Rendah ASTM A36 Pada Lingkungan Atmosferik di kabupaten Jember. Jurnal Rotor, Vol 5, No 1.

Tjitro, S., Anggono, J., Anggorowati, A. A., \& Phengkusaksomo, G. (2000). Studi 
Prilaku Korosi Tembaga dengan Variasi Konsentrasi Asam Askorbat (Vitamin C) dalam Lingkungan Air Yang Mengandung Klorida dan Sulfat. Jurnal Teknik Mesin, 62-67, Vol. 2, No. 1.

Threthewey, K. R. (1991). Korosi Untuk Mahasiswa Sains dan Rekayasa. Jakarta: PT Gramedia Pustaka Utama. Hlm 63-89. 